\title{
Danube Delta Coastline Dynamics in the last 160 years
}

\author{
Florin Tătui, Alfred Vespremeanu-Stroe, Florin Zăinescu, Ștefan Cnstantinescu \\ Faculty of Geography \\ University of Bucharest \\ Bucharest, Romania \\ florin.tatui@geo.unibuc.ro
}

\begin{abstract}
Danube Delta coastline experienced variable dynamics in the last $\mathbf{1 6 0}$ years, depending on the factors and processes which had the leading role at different temporal and spatial scales. At centennial time-scales, shoreline evolution was highly influenced by the threefold decrease of Danube sediment discharge in the last century, while on multi-decadal scale, storminess (as a result of climate variability) was the driving factor for coastline changes. Overall, human influence superposed on the natural response of the coast to variability of climatic, hydrological and hydrodynamic (marine) factors. All these changes resulted in different shoreline morphology and configuration along Danube Delta coast.
\end{abstract}

Keywords - erosion/progradation; LST; river sediment discharge; storminess; climate variability

\section{INTRODUCTION}

Shorelines exhibit considerable variations of their position over a wide range of spatial and temporal scales. On sandy coasts, shoreline accretion and erosion are generally associated to low- and high-energy wave conditions.

Wave-dominated deltaic coasts depend on the balance between wave climate and sediment supply ([1], [2]), which controls the medium and long-term shoreline evolution. Interestingly, the common plan shapes of the wave-dominated lobes impose different wave exposures and longshore sediment transport magnitudes on the lobe flanks, characterized by ever changing aspects which make these sandy coasts some of the most mobile world coastlines.

The objective of this study is to examine and explain the factors which have driven the Danube Delta coastline dynamics at multi-annual to multi-decadal and centennial time-scales in the last 160 years.

\section{GENERAL DATA}

\section{A. Study Area}

The Danube Delta coast (both Romanian and Ukrainian sectors) consists of approximately $220 \mathrm{~km}$ of tideless, medium-energy low-lying sandy beaches interrupted by multiple river mouths and, sometimes, by engineering structures (Fig. 1). The Romanian Danube Delta coast consist of five littoral cells, most of them being dominated by erosion. Waves from the north-eastern directions are dominant in terms of both magnitude and frequency, inducing a strong net southward oriented longshore sediment transport (LST) on most coastal sectors along Danube Delta coast.

\section{B. Data \& Methods}

Our analysis is based on multiple shorelines extracted from historical and modern maps (since mid-19th century), recent medium to high resolution satellite images (since 1984), aerial photos (since 1969), GPS surveys (available after 1990) and LIDAR data (2011), which were comparatively analyzed by means of GIS techniques (Digital Shoreline Analysis System-DSAS; [3]).

\section{RESUlTS AND DISCUSSIONS}

Nowadays, more than half ( $55 \%$ ) of the Romanian Danube Delta shoreline is affected by erosion. The present coastline configuration is the result of the long-term evolution of this deltaic coast. In the last 160 years, shoreline evolution on different sectors of the Danube Delta was dominated by either accumulation or erosion. The accumulation sectors showed mean shoreline progradation rates varying from 10-25 m/year, for Sulina beach and Sf. Gheorghe secondary delta, to 40-70 m/year, along Chilia secondary delta. They are linked to various driving factors and processes as follows:

- active deltaic lobes (Chilia and Sf. Gheorghe secondary delta), in direct connection with high Danube sediment discharge;

- updrift beaches of natural river mouths (Sf. Gheorghe), dominated by accumulation induced by morphologic (mouth bar) and hydrodynamic (river plume) groin effect on the longshore sediment transport (LST);

- engineering structures (jetties and harbor dykes), inducing accumulation either updrift (Midia Harbor) or 
immediately downdrift (Sulina jetties, as a result of wave diffraction and formation of eddy-like counter-currents).

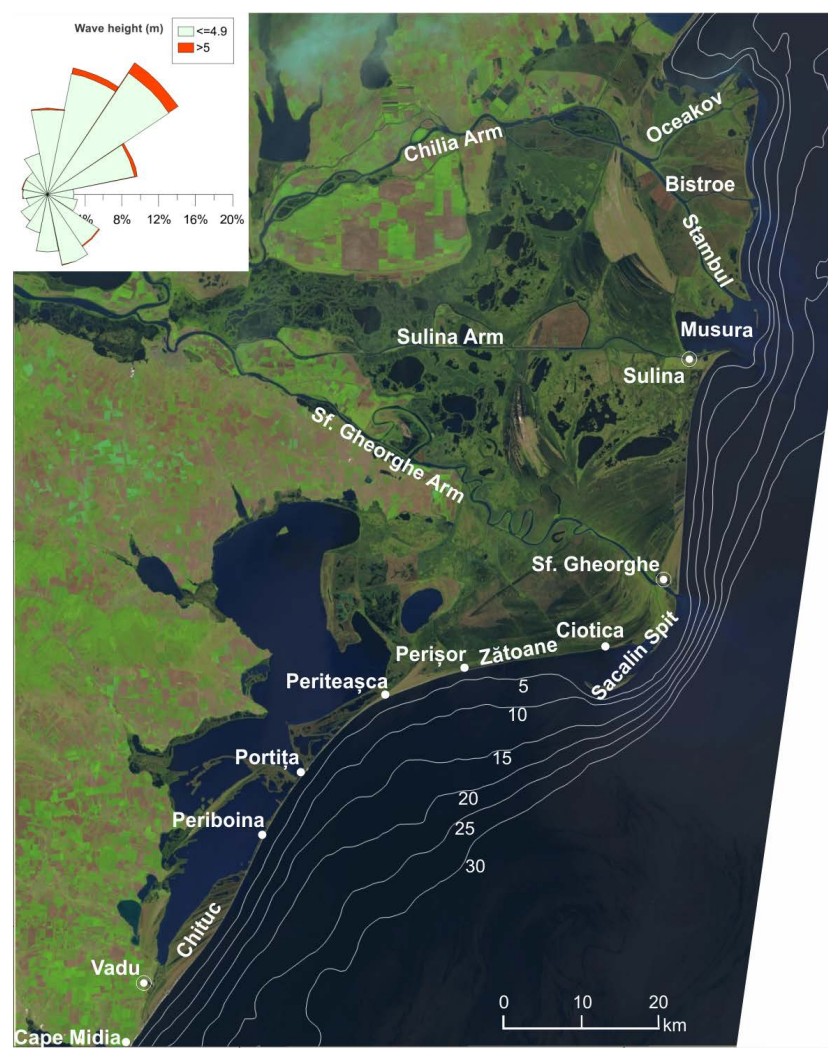

Fig. 1. Danube Delta coast (LANDSAT image from May 2013).

Contrary, the erosive areas registered mean shoreline retreating rates of maximum $20 \mathrm{~m}$ /year and are associated to:

- the boundary between two littoral cells (overlaid on the divergence zones of nearshore currents) and the updrift sectors of stable littoral cells (i.e. central part of Sulina-Sf. Gheorghe coast, Zătoane and Portiţa Periboina sectors);

- the long-term retreating deltaic lobes following their abandonment, which let protuberant coasts exposed to wave reworking (Sulina), whose erosion was intensified by the lack of longshore supplied sediments due to river jetties construction.

Depending on the temporal and spatial scales taken into consideration, different driving forces changed the leading role in the dynamics of Danube Delta shoreline in the last 160 years.

At centennial time-scale, the threefold decrease of Danube sediment discharge in the last century (especially after 1950, as a result of dams'construction in the Danube watershed - [4]) explains the significantly higher shoreline migration rates and area changes between 1856 and 1961/1979 in comparison with the subsequent period, especially along the accumulative sectors (Fig. 2). For the Chilia prograding lobe, this resulted in the decrease with more than $75 \%$ of the progradation rates and with approximately $90 \%$ of the corresponding area change rates, marking its transition, since mid-20th century, from fluvial-dominated morphology to wave-influenced aspect and behavior ([5]). This resulted in a change of coastline configuration from a crenulated shoreline (in $19^{\text {th }}$ century and the beginning of $20^{\text {th }}$ century) to progressive shoreline straightening (1935 - 1980) and the development of spits and barrier islands (after 1980) - [6] .

Also, since the beginning of the 20th century, the asymmetric Sf. Gheorghe lobe experienced dramatic changes of its millennial prograding pattern expressed by the complete cessation of the updrift coastal progradation and the prevalence of erosion in front of the river mouth, whose sediments are feeding far-positioned downdrift depocentres. These changes are reflected by the recent (1930-present) river mouth dynamics, characterized by cessation of its long-term seaward expansion in favor of downdrift migration, indicating the transition of the Sf. Gheorghe mouth from an asymmetric to a deflected waveinfluenced delta morphology.

The erosive sectors presented a much lower variability in terms of both shoreline retreat and erosional surface rates between the two analyzed time intervals (Fig. 2).

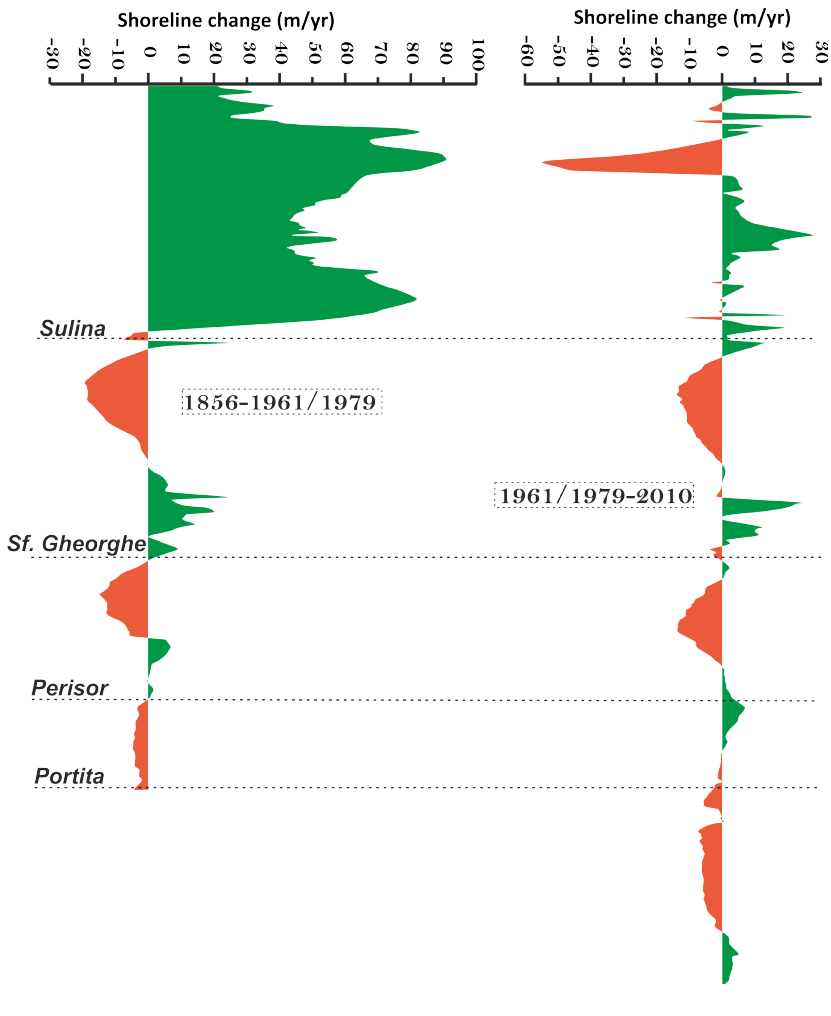

Fig. 2. Different shoreline changes/behaviour between 1856-1961/1979 and 1961/1979-2010 time intervals.

At multi-decadal scale, different modes of climate variability (e.g. North Atlantic Oscillation) control the storminess variations along the Danube Delta coast. Hence, active storminess during 1961-1979 time interval determined very high shoreline dynamics, with two-three times higher shoreline migration rates than afterwards, when a decrease in storminess favored less dynamic coastlines (on both prograding and erosive sectors) - [7]

At inter-annual scale, waterline mobility is influenced by storm regime and river floods.

Nowadays, coastal engineering structures play a very important role in shoreline behavior. For example, Sulina jetties (which are currently developing approximately $9 \mathrm{~km}$ offshore) interrupt the dominant southward directed longshore drift, altering nearshore circulation and inducing high accumulation rates updrift (Musura Bay) or immediately downdrift (Sulina beach), whilst an increasing coastal erosion occurs for large areas downdrift. 


\section{CONCLUSIONS}

In the past 160 years of evolution, Danube Delta coastline experienced significant morphodynamic variability related to different driving forces which changed the leading role between them depending on the considered temporal and spatial scales.

At centennial time-scale, the threefold decrease of Danube sediment discharge in the last century (especially after 1950, as a result of dams'construction in the Danube watershed) explains the significantly higher shoreline migration rates and area changes between 1856 and $1961 / 1979$ in comparison with the subsequent period, especially along the accumulative sectors of secondary deltas.

At multi-decadal scale, different modes of climate variability (e.g. North Atlantic Oscillation) control the storminess variations and, ultimately, the coastal processes intensity along the Danube Delta coast.

Our findings should support the sustainable coastal management and planning, providing a better understanding of past and present coastal processes along the Danube Delta coast.

\section{ACKNOWLEDGMENT}

This study was financed by the Romanian National Authority for Scientific Research (CNCS-UEFISCDI) and European Union (EU) under ERA.NET RUS-Plus grant no. 42/2016 (BS STEMA) awarded to AVS.

\section{REFERENCES}

[1] J.M. Coleman and L.D. Wright, "Modern river deltas; variability of processes and sand bodies”, in Deltas, models for exploration, M.L. Broussard, Ed. Houston Geological Society, 1975, pp. 99-149.

[2] J.P. Bhattacharya and L. Giosan, "Wave-influenced deltas: geomorphological implications for facies reconstructions", Sedimentology, vol. 50, pp. 187-210, 2003.

[3] E.R. Thieler, E.A. Himmelstoss, J.L. Zichichi and A. Ergul, "Digital shoreline analysis system (DSAS) version 4.0-an ArcGIS extension for calculating shoreline change”. U.S. Geological Survey Open-File Report 2008-1278, 2009.

[4] L. Preoteasa, A. Vespremeanu-Stroe, A., F. Tătui, F. Zăinescu, A. Gabor-Timar and I. Cîrdan, "The evolution of an asymmetric deltaic lobe (Sf. Gheorghe, Danube) in association with cyclic development of the river-mouth bar: Long-term pattern and present adaptations to human-induced sediment depletion", Geomorphology, vol. 253, pp. 59-73, 2016.

[5] A. Vespremeanu-Stroe, A., F. Tătui, S. Constantinescu and F. Zăinescu, "Danube Delta Coastline Evolution (1856-2010)”, in Landform Dynamics and Evolution in Romania, M. Rădoane and A. Vespremeanu-Stroe, Eds. Springer International Publishing, 2017, pp. 551-564.

[6] A. Vespremeanu-Stroe and L. Preoteasa, "Morphology and the cyclic evolution of Danube Delta spits”, in Sand and gravel spits, G. Randazzo, A. Cooper and D. Jackson J., Eds. Springer International Publishing, 2015, pp. 327-339.

[7] A. Vespremeanu-Stroe, S. Constantinescu, F. Tătui and L. Giosan, "Multi-decadal evolution and North Atlantic Oscillation influences on the dynamics of the Danube delta shoreline”, Journal of Coastal Research, vol. 50, pp. 157-162, 2007. 